H. M. Blom · T. Godthelp · W. J. Fokkens · A. Klein Jan

A. F. Holm · T. M. Vroom · E. Rijntjes

\title{
Mast cells, eosinophils and IgE-positive cells in the nasal mucosa of patients with vasomotor rhinitis
}

\section{An immunohistochemical study}

Received: 15 April 1994

\begin{abstract}
Vasomotor rhinitis (VMR) is a disorder of unknown pathogenesis. Forty patients with VMR were carefully selected on the basis of inclusion and exclusion criteria proposed by Mygind and Weeke. Nasal biopsy specimens were taken in the patient group as well as in a group of ten controls. Brush cytology was also taken in the VMR group. Inflammatory cells were identified and counted in the nasal mucosa, with the use of immunohistochemical techniques and a panel of monoclonal antibodies. Eosinophils were studied with the use of BMK13, EG2, and Giemsa. Mast cells were studied with anti-chymase (B7), anti-tryptase (G3) and toluidine blue. Sections were stained with $\operatorname{IgE}$ as well. There was no significant difference in the number of eosinophils, mast cells and IgE-positive cells between the two groups. Additionally, in contrast with other reports, in sections that were double-stained with anti-chymase and anti-tryptase, single chymase-positive cells were found.
\end{abstract}

Key words Vasomotor rhinitis - Eosinophils $\cdot$ Mast cells Pathophysiology $\cdot$ Anti-chymase $\cdot$ Anti-tryptase

H. M. Blom (区) · T. Godthelp · W. J. Fokkens · A. F. Holm Department of Otorhinolaryngology,

University Hospital Dijkzigt, Dr. Molewaterplein 40, 3016 GD Rotterdam, The Netherlands

T. Godthelp - A. Klein Jan

Department of Immunology, Erasmus University,

Rotterdam, The Netherlands

E. Rijntjes

Department of Otorhinolaryngology, Leyenburg Hospital,

The Hague, The Netherlands

T. M. Vroom

Department of Pathology, University of Utrecht,

Utrecht, The Netherlands

\section{Introduction}

Rhinitis is subdivided into a number of different entities, one of which is vasomotor rhinitis (VMR) [12]. This term usually describes a chronic type of rhinitis with nasal congestion, rhinorrhea and sneezing for which no plausible explanation can be found. In 1981 VMR was subcategorized based on nasal eosinophilia and the term "NARES" (non-allergic rhinitis with eosinophilia syndrome) was introduced [7].

By its nature as a diagnosis by exclusion, VMR represents a heterogeneous group of pathophysiological conditions. Faced with this group of patients with non-atopic nasal complaints, we excluded all patients with systemic, medical, and anatomical disorders that could explain complaints of rhinorrhea, sneezing, and nasal obstruction. This group with unexplainable nasal complaints was then homogenized on the basis of a daily record chart on which patients had to reach a minimum symptom score. The minimum was set using as a basis the definition of rhinitis put forward by Mygind and Wihl [25] in 1985. In affected patients periods of nasal discharge, sneezing and congestion had to persist for an average of at least $30 \mathrm{~min}$ to $1 \mathrm{~h}$ per day.

Since VMR, according to prevailing theory, is thought to be the result of a neurogenic disorder [8], various authors have focussed on the neurogenic system by studying, for example, nasal mucosal innervation or neuropeptide distribution [26]. Others have examined functional aspects using such provocational agents as histamine and metacholine [5], neuropeptides [26], and non-pharmacological agents such as cold, dry air [23], saline solutions and iso-osmolar ultrasound mist. Different therapeutic regimens including such treatments as topical steroids [18], ipatropium bromide [1], and various surgical interventions $[9,16,19]$ have been studied as well.

In the present study we investigated the cellular infiltrates in the nasal mucosa of patients with a known VMR. To our knowledge, this subject has not been addressed before. It is well known that in atopic rhinitis, for example, cells such as eosinophils, mast cells, antigen presenting 
Table 1 Criteria for the selection of patients with vasomotor rhinitis (VMR)

\begin{tabular}{l} 
Inclusion criteria \\
- Age between 16 and 65 years \\
- Negative skin prick test and negative RAST score \\
- Symptoms for more than 1 year \\
- A cumulative score of 5 or more for the following nasal \\
parameters: \\
blockage, clear discharge and sneezing for at least 7 days \\
during a period of 14 days. \\
Exclusion criteria \\
- The use of systemic or inhaled corticosteroids within the \\
previous month \\
- The use of inhaled sodium cromoglycate or nedocromil \\
sodium within the previous month \\
- The use of astemizole within the previous month \\
- Inability of the patient to stop taking therapy \\
affecting nasal function \\
- A serious and/or unstable disease \\
- Nasal surgery within the previous 3 months \\
- Significant anatomical abnormalities affecting nasal function \\
- Nasal polyps or a history of nasal polyps \\
- Nasal or paranasal sinus infection \\
- Abnormal sinus X-ray \\
- Pregnancy or lactation \\
- Abnormal laboratory results for: \\
blood: Na, K, Ca, total protein, albumin, urea creatinine, \\
bilirubin, alkaline phosphatase, aspartate aminotransferase, \\
alanine aminotransferase, gamma glutamyl transpeptidase, \\
hemoglobin, red blood cell count, plasma cell volume, mean \\
corpuscular volume, platelets, total white blood cell count, \\
neutrophils, lymphocytes, monocytes, eosinophils, basophils \\
- urine: blood, protein, glucose \\
- Abnormal findings at physical examination \\
\hline
\end{tabular}

\section{Materials and methods}

Patients were studied from 1988 to 1992 in the outpatient ENT Department of Leyenburg Hospital in The Hague, The Netherlands. Patients were admitted to the study if they had a history of nasal complaints such as nasal obstruction, sneezing, and rhinorrhea for a period of more than 1 year and these symptoms could not be attributed to an atopic rhinitis, nasal or paranasal sinus infection, anatomical disorders affecting nasal function, pregnancy or lactation and/or systemic disorders (Table 1). Patients with nasal polyps were also excluded, since they may belong to a different pathophysiological group and their polyps may contribute to a higher symptom score for nasal blockage and/or rhinorrhea. Of those individuals selected, 155 patients scored their nasal complaints for a period of 2 weeks using our daily record chart (DRC) (Table 2). The duration of complaints during the day was then used as the prime criterion for further study [25]. Patients had to have a cumulative score of 5 or more for the following nasal parameters: blockage, clear nasal discharge, and sneezing for at least 7 days during a period of 14 days. Forty of the 155 patients were found eligible for our study and participated under conditions of informed consent.

A nasal brush sample for cytology and a mucosal biopsy specimen were taken from all 40 patients. Ten healthy volunteers without nasal complaints or nasal abnormalities on ENT examination and a negative skin prick test were biopsied once and tissue specimens used as controls.

\section{Nasal biopsies}

At the time of biopsy, all patients had nasal complaints, as confirmed by their DRCs. After randomization of the biopsy side, specimens of nasal mucosa were taken from the lower edge of the inferior turbinate, about $2 \mathrm{~cm}$ posterior to the front edge, using a Gerritsma forceps with a cup diameter of $2.5 \mathrm{~mm}$ [3].

Local anesthesia was obtained by placing a cotton-wool carrier with $50 \mathrm{mg}$ cocaine and one drop of adrenaline $(1: 1000)$ under the inferior turbinate but without touching the biopsy site. The specimens were embedded in Tissue-Tek II O.C.T. compound and frozen immediately.

Nasal brush cytology

Contralateral to the biopsy side a nasal brush sample was taken from the middle nasal fossa using the Gynobrush (Medeco, Eindhoven, The Netherlands). This is a modification of the technique advocated by Pipkorn [10]. In our experience, this brush is less painful than the Rhinobrush (also Medeco). The brush was immediately placed in RPMI. Within 3 days cytospin preparations were made and cells were stained with Giemsa and toluidine blue.
Table 2 Scheme of the daily record chart for defining nasal symptoms in patients with vasomotor rhinitis
Possible scores on the daily record chart

$\begin{array}{ll}\text { Nasal blockage } & \begin{array}{l}0=\text { absent } \\ \text { (not being able to breathe freely through the nose): }\end{array} \\ & \begin{array}{l}1=\text { between } 0-1 \mathrm{~h} \text { per half day } \\ 2=\text { between } 1-2 \mathrm{~h} \text { per half day } \\ 3\end{array} \\ \text { Clear nasal discharge (runny nose): } & \begin{array}{l}0=\text { more than } 2 \mathrm{~h} \text { per half day } \\ \text { Sneezing: }\end{array} \\ & 1=\text { less than } 5 \text { periods per half day } \\ & 2=\text { between } 5-10 \text { periods per half day } \\ & 3=\text { more than } 10 \text { periods per half day } \\ & 0=\text { absent } \\ \text { Mucus production (yellow, green or brown): } & 1=\text { present }\end{array}$

Remarks: All other medical complaints and medication taken during the day should be noted cells and T-cells present in the nasal mucosa are involved in the pathogenesis and sustaining of this disorder $[4,11]$. took brush samples from VMR patients and biopsy samples from both VMR patients and controls. Biopsies were state of eosinophils as well as the occurrence and localization of mast cells and other surface IgE-positive cells. 
Table 3 Monoclonal antibodies and histochemical dyes used to study mucosal biopsies in patients with VMR and controls $(M B P$ major basic protein, $E C P$ eosinophilic cationic protein)

\begin{tabular}{|c|c|c|c|}
\hline Antibody & Titer & Specificity & Source \\
\hline BMK 13 & $1: 200$ & MBP & Sanbio, Uden, The Netherlands (NL) \\
\hline EG2 & $1: 40$ & $\mathrm{ECP}$ & Pharmacia, Woerden, NL \\
\hline$\alpha-\operatorname{IgE}$ & $1: 250$ & $\operatorname{IgE}$ & $\begin{array}{l}\text { Central Laboratory of The Netherlands Red Cross } \\
\text { Blood Transfusion Service (CLB), Amsterdam, NL }\end{array}$ \\
\hline B7 & $1: 100$ & Chymase & Chemicon, Temecula, Calif, USA \\
\hline G3 & $1: 250$ & Tryptase & Cehmicon, Temecula, Calif, USA \\
\hline \multicolumn{3}{|c|}{ Histochemical dyes } & Source \\
\hline \multicolumn{3}{|l|}{ Giemsa } & Merck, Amsterdam, NL \\
\hline \multicolumn{3}{|c|}{ Toluidine blue } & B.D.H, Dorset, UK \\
\hline
\end{tabular}

Staining procedures

\section{Eosinophils}

The monoclonal antibodies $(\mathrm{mAb}) \mathrm{BMK} 13, \mathrm{EG} 2$ and Giemsa (Table 3) were used together with the immuno-alkaline phosphatase, anti-alkaline phosphatase (APAAP) method. BMK13 is a $\mathrm{mAb}$ against major basic protein and is reported to stain $95-97 \%$ of all eosinophils [13]. EG2 is a mAb against eosinophilic cationic protein and stains the activated eosinophils [22].

Sections of nasal mucosa were cut in $6 \mu \mathrm{m}$ thicknesses on a cryostat (Jung Frigocut $2800 \mathrm{E} / 20 / 40$ ), transferred to poly-L-lysinecoated microscope slides, dried, and fixed in acetone for $10 \mathrm{~min}$ at $20^{\circ} \mathrm{C}$. They were next rinsed in phosphate-buffered saline (PBS, $\mathrm{pH}$ 7.2), placed in a half-automatic stainer (Sequenza, Shandon), incubated with $2 \%$ bovine serum albumin in PBS for $10 \mathrm{~min}$ and incubated with normal rabbit serum (CLB, Amsterdam, The Netherlands) for $10 \mathrm{~min}$. Following this the slides were incubated with the $\mathrm{mAb}$ for $30 \mathrm{~min}$ at $20^{\circ} \mathrm{C}$. The sections were then rinsed again in PBS for $5 \mathrm{~min}$ and incubated for $30 \mathrm{~min}$ with a rabbit antimouse $(1: 20)$ immunoglobulin antiserum, rinsed successively in PBS, incubated with APAAP (1:40) (Dakopatts, Copenhagen, Denmark) for $30 \mathrm{~min}$ at $20^{\circ} \mathrm{C}$, rinsed in PBS and TRIS buffer ( $\mathrm{pH}$ 8.0), and incubated for 30 min with a new fuchsin substrate (Chroma, Kongen, Germany). Finally, sections were rinsed with distilled water, counterstained with Mayer's hematoxylin, and mounted in glycerin-gelatin. Control staining was performed by substitution with PBS and incubation with an irrelevant $\mathrm{mAb}$ of the same subclass.

\section{Mast cells}

Toluidine blue, an aniline dye, stains mast cells metachromatically. Tissue sections were stained with toluidine blue at $\mathrm{pH} 0.5$ for $5 \mathrm{~min}$ and counts were performed immediately [4]. The $\mathrm{mAbs}$ anti-chymase (B7) and anti-tryptase (G3) are mast cell specific [6]. To check our atopic screening, the biopsy material was also stained with anti-IgE, since atopic patients usually have a large number of IgE-positive cells present in biopsy sections [4]. For staining with anti-IgE, G3 and B7 (Table 3) supersensitive AP was used (BioGenex AZ000UM). This protocol followed the APAAP protocol up to the first PBS rinse. Sections were then incubated with normal goat serum (CLB, Amsterdam, The Netherlands) for $10 \mathrm{~min}$ and then for $60 \mathrm{~min}$ with the $\mathrm{mAb}$. The sections were rinsed with PBS for 5 min and succesively linked with biotinylated anti-mouse serum for $30 \mathrm{~min}$, rinsed with PBS for 5 min, and labeled with streptavidin-AP (ssAP) for $30 \mathrm{~min}$. They were next rinsed in PBS for $5 \mathrm{~min}$ and TRIS buffer $(\mathrm{pH} \mathrm{8.0)}$ ) for $5 \mathrm{~min}$, and then incubated for $30 \mathrm{~min}$ with new fuchsin, after which the protocol again conformed to the APAAP protocol. Furthermore, for a general evaluation and control counting of eosinophils, hematoxylin-eosin (HE) and Giemsa staining were performed.
Double staining of mast cells was achieved by incubation with anti-chymase, linked with biotinylated anti-mouse and labeled with steptavidin $\beta$-D-galactoside for $60 \mathrm{~min}$. The sections were then incubated with anti-tryptase AP for 60 min, after which samples were incubated with $\beta$-D-galactoside substrate and new fuchsin substrate. Slides were mounted in glycerin.

\section{Light-microscopic evaluation}

Stained cells were counted in two sections of each biopsy specimen. The epithelium and lamina propria were evaluated separately. The total surface area of a section and its main parts (i.e., the epithelium and lamina propria) were estimated with the use of the Kontron Image Analysis System Videoplan. The number of cells $/ \mathrm{mm}^{2}$ was calculated for the epithelium and the lamina propria.

\section{Statistical analysis}

The Mann-Whitney U-test was used to compare the differences in cell counts between the groups. A $P$ value $<0.05$ was considered to indicate a significant difference.

\section{Results}

\section{Biopsy specimens}

The sections of nasal mucosa had an average surface area of $1.5 \mathrm{~mm}^{2}$ and were generally of good quality. All but two biopsy specimens were evaluated. One exclusion was made because of artifact resulting from defrosting of the specimen and the other specimen was displaced. The mAb-APAAP and the mAb-ssAP staining showed red cells against a blue counterstained background. After toluidine-blue staining, mast cells could easily be identified by their dark-violet, metachromatic granules against a background of faintly stained tissue.

\section{Eosinophils}

The numbers of Giemsa-positive, BMK13-positive and EG2-positive cells $/ \mathrm{mm}^{2}$ are shown in Table 4. Virtually no eosinophils were present in the lamina propria and the epithelium of both groups and any differences between the two groups were not statistically significant. 
Table 4 Median and range (..) of numbers of eosinophils, mast cells and other IgE-positive cells in the nasal mucosa of patients with vasomotor rhinitis and controls

\begin{tabular}{llll}
\hline Eosinophils & Patients $(n=40)$ & $\begin{array}{l}\text { Controls }(n=10) \\
\text { Median (range) }\end{array}$ & $P$ value \\
& Median (range) & \\
\hline
\end{tabular}

\section{Epithelium}

BMK13

EG2

Giemsa

$0(0-281)$

$0(0-128)$

$0(0-209)$

$0(0-53)$

$0(0)$

$0(0-9)$

Not significant

Not significant

Not significant

Lamina propria

BMK13 $0(0-350) \quad 0(0-6)$

EG2 $\quad 0(0-56) \quad 0(0)$

Giemsa

$0(0-124)$

$0(0-1)$

Not significant

Not significant

Not significant

\begin{tabular}{llll}
\hline Mast cells and IgE + cells & $\begin{array}{l}\text { Patients }(n=40) \\
\text { Median (range) }\end{array}$ & $\begin{array}{l}\text { Controls }(n=10) \\
\text { Median (range) }\end{array}$ & $P$ value \\
\hline $\begin{array}{l}\text { Epithelium } \\
\text { Toluidine blue }\end{array}$ & $0(0-138)$ & $0(0-4)$ & Not significant \\
Anti-tryptase & $0(0-282)$ & $0(0-29)$ & Not significant \\
Anti-chymase & $0(0-40)$ & $0(0-3)$ & Not significant \\
Anti-IgE & $0(0-480)$ & $0(0-198)$ & Not significant \\
Lamina propria & & & Not significant \\
Toluidine blue & $22(0-101)$ & $17(19-51)$ & Not significant \\
Anti-tryptase & $74(1-162)$ & $70(9-96)$ & Not significant \\
Anti-chymase & $75(25-238)$ & $54(24-83)$ & Not significant \\
Anti-IgE & $21(0-338)$ & $7(0-152)$ & \\
\hline
\end{tabular}

\section{Mast cells and other IgE-positive cells}

The numbers of toluidine-blue-positive, G3-positive, B7positive and anti-IgE positive cells $/ \mathrm{mm}^{2}$ are shown in Fig. 1. The number of B7-positive cells tended to be higher than the number of G3-positive cells in both patients and controls. Both tended to be higher than the number of toluidine-blue-positive cells. There were no significant differences between the two groups as to cell numbers in the epithelium and lamina propria (Fig. 2) for the various staining methods. Biopsy specimens from 2 of 40 patients showed substantial numbers of eosinophils, mast cells, and IgE-positive cells.

\section{Brush material}

A total of 500 cells were counted per cytospin. Toluidineblue-positive cells were found in just one cytopsin (50 toluidine-blue-positive cells per 500 counted cells). Eosinophils were not found.

\section{Discussion}

We selected 155 patients with a history of nasal complaints for which no explanation could be found. However, only 40 of these patients satisfied our condition for inclusion in our study of nasal complaints for more than $1 \mathrm{~h}$ a day. That patients often overestimate nasal complaints underscores the importance of the use of DRCs to characterize patients objectively. The duration of complaints was used as our prime criterion. It is also common knowledge that subjective complaint scores in which the intensity of the complaints are graded can be influenced by a patient's state of mind. On a bad day, patients suffer more. Moreover, it is easier for a patient to score the duration of the complaints than to grade intensity.

Biopsies from two patients with VMR had substantial numbers of IgE-positive cells, mast cells, and eosinophils. As a consequence, we feel that these patients were indeed allergic in spite of their negative allergy tests. The data of these two patients were included since they satisfied our overall inclusion criteria.

\section{Brush cytology}

VMR patients with prominent nasal eosinophilia of $20 \%$ or more are subcategorized as NARES patients. In general the NARES group comprises $10-13 \%$ of the VMR patients [14]. Contrary to expectations, none of our patients showed eosinophilia in cytospin preparations of brush samples. This might be explained by the eosinophilic subgroup being more susceptible to therapy [20]. The use of nasal corticosteroids has gained increasing acceptance by the general practitioner during the last decade. It is thus possible that most NARES patients are less symptomatic with nasal corticosteroid spray and are therefore not referred to the ENT surgeon for further care. This hypothe- 

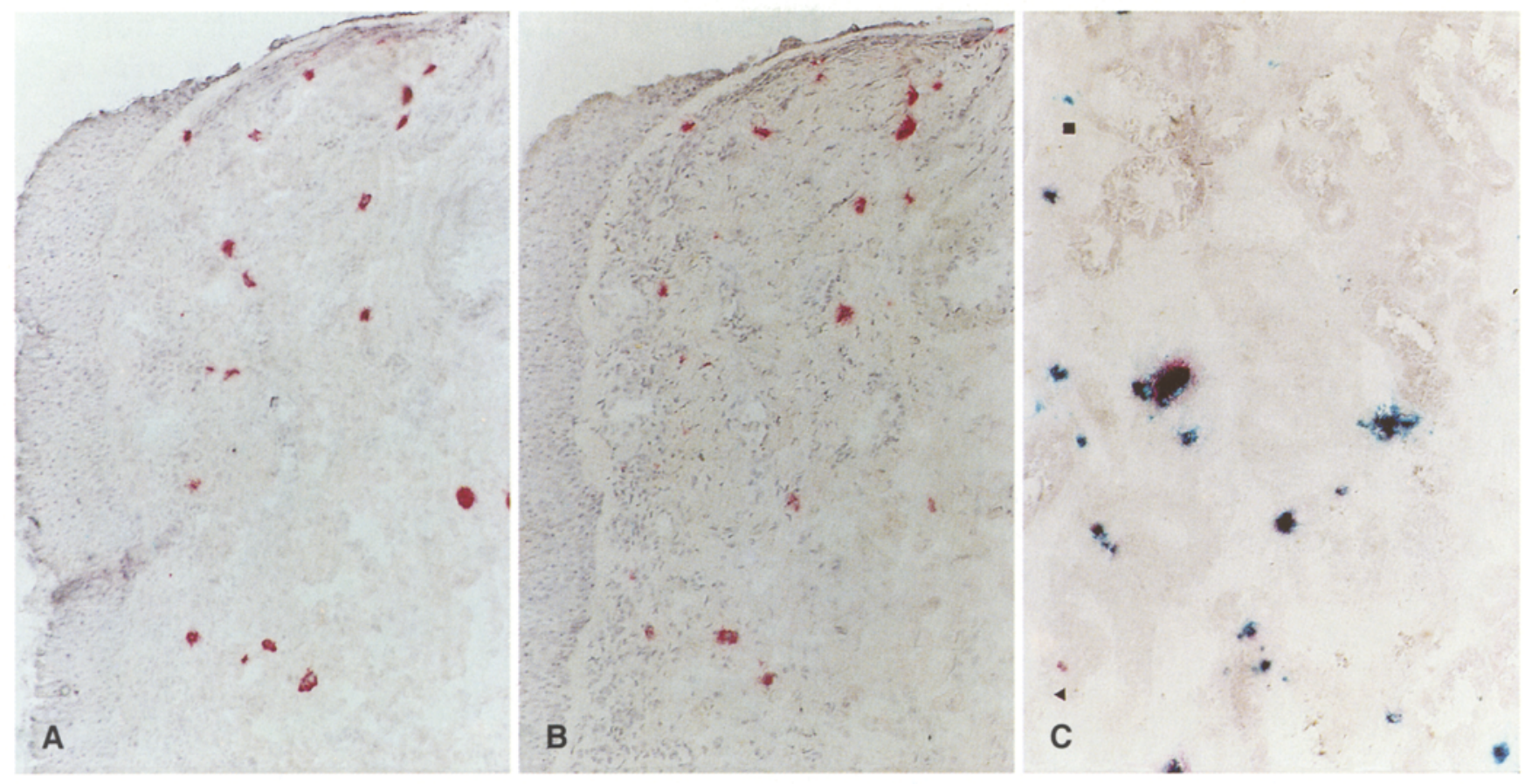

Fig. 1A-C Serial sections of nasal mucosal biopsies. A Nasal mucosa stained with anti-chymase. B Nasal mucosa stained with anti-tryptase. C Nasal mucosa stained with anti-chymase (green) and anti-tryptase (red). Single anti-chymase cells are indicated by squares. Single anti-tryptase cells are indicated by triangles. The sections are slightly counterstained with hematoxylin and eosin. $\times 170$

sis is supported by the finding in our group of patients that congestion was the primary symptom. In NARES patients sneezing and clear rhinorrhea are the main symptoms. Moreover, although in the eosinophilic subgroup polyps are seen clinically in $30 \%$ of cases, polyps were an exclusion criterion in our series.

\section{Biopsy specimens}

\section{Eosinophils}

Since virtually no eosinophils were found with Giemsa or BMK13, not to mention activated eosinophils (i.e., EG2positive cells), in biopsy specimens from our patients and controls, we currently believe that these cells are not important in the pathogenesis of VMR, excluding NARES.

\section{Mast cells}

Anti-tryptase is reported to stain all mast cells while some of these tryptase-positivie cells are also positive for chymase [6]. Contrary to our expectation, the number of chymase-positive cells was not lower than the number of tryptase-positive cells in our present study. Additionally, in sections that were double-stained with anti-chymase and anti-tryptase, single chymase-positive cells were found (Fig. 1). We think that this is the result of our fixation method. While other authors all use Carnoy's solution for mast cell fixation, we fixed our sections with acetone. We then found fixation with Carnoy's solution drastically reduced the numbers of chymase-positive and toluidine-blue-positive cells, whereas the number of tryptasepositive cells was only slightly reduced. We therefore prefer acetone fixation.

Apart from the two biopsies that were previously mentioned, virtually no mast cells were found in the nasal epithelium from controls and patients. As reported by Okuda et al. [17] the predominant metachromatic cell in the lamina propria of the nasal mucosa is the mast cell, the basophilic neutrophil that can also be stained with toluidine blue, is generally not present in the lamina propria of the nasal mucosa. This is in accordance with our findings.

To our surprise we found no evidence for mast cell involvement in VMR. In allergic rhinitis cross-linking of $\operatorname{IgE}$ on the membrane of the mast cells and the subsequent release of mast cell mediators (degranulation) is thought to contribute substantially to the complaints associated with rhinitis. We detected no specific IgE (by RAST and skin-prick test) and there was no significant difference in the number of IgE-positive cells between our VMR patients and the controls. Apart from the two biopsies with substantial numbers of eosinophils, mast cells and antiIgE positive cells, no evidence for degranulation as a result of IgE cross-linking was found. Separate studies have shown that neuropeptides have been found to induce degranulation in mast cells [2]. Support for neuropeptide involvement in VMR has been found by investigations demonstrating a reduction in nasal complaints associated with a depletion of sensory neuropeptides by prior treatment with capsaicin [21]. A recent study by Lacroix's 
Fig. 2 Mast cells and other IgE-positive cells in the lamina propria of the nasal mucosa of patients with vasomotor rhinitis $(n=40)$ and controls $(n=10)$. Significant differences were found between the number of toluidine-blue-positive cells and the number of anti-chymasepositive cells. No significant differences were found between the number of antitryptase-positive cells and the number of anti-IgE-positive cells. Group median values are represented by horizontal bars

\section{Toluidine-blue-positive cells in the lamina propria}

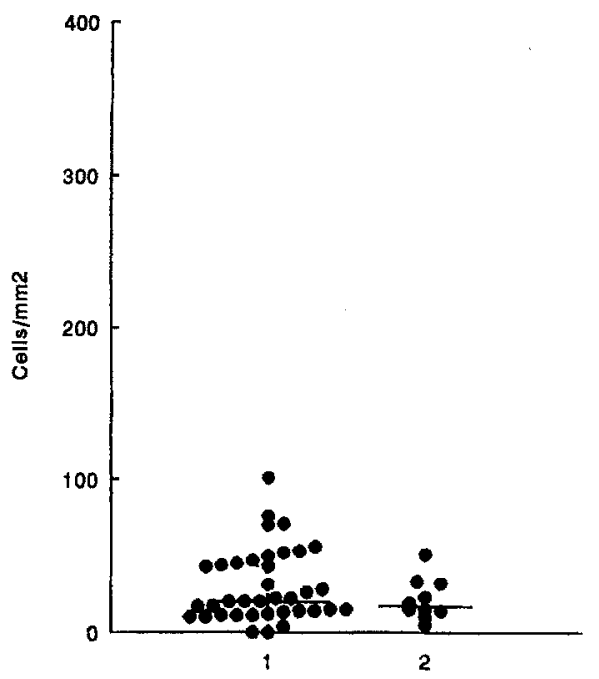

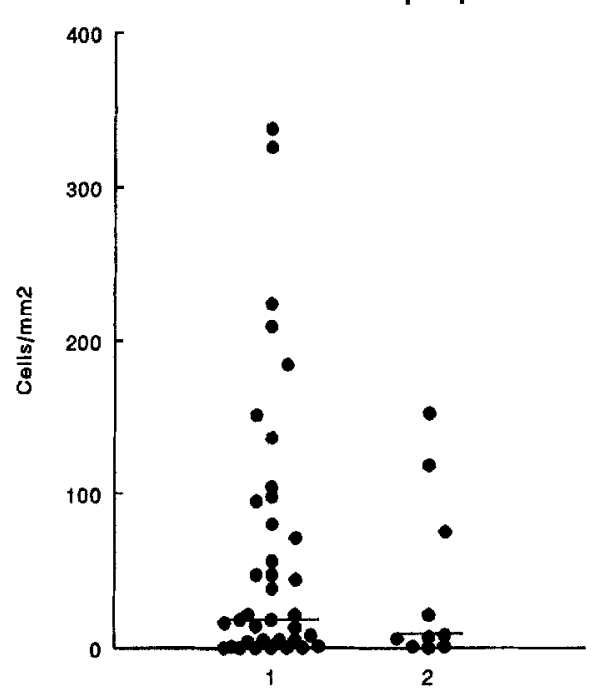

IgE-positive cells in the lamina propria

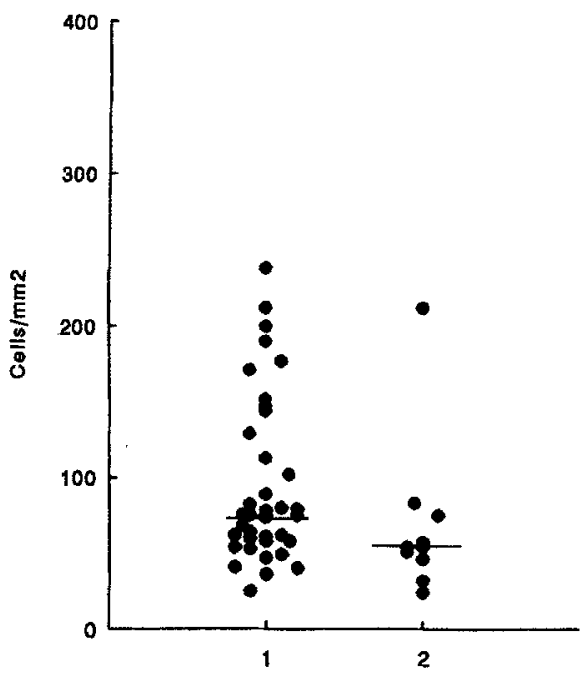

group [11] also found an increased concentration of sensory neuropeptides in the nasal mucosa of patients with chronic non-allergic rhinitis.

One could hypothesize that an increased neuropeptide content could induce an ongoing degranulation of mast cells and thus a release of mast cell mediators, resulting in a possible decrease in mast cell numbers. However, a reduction in mast cell numbers was not found in our group of patients. Further evaluation of mast cell degranulation by electron microscopy studies is in progress. In the near future we will report on the involvement of T-cell subsets, and other inflammatory cells, including cytokine production.
Acknowledgements $T$. van Os is acknowledged for the preparation of the pictures used in this study and E. van Schaick gave enthusiastic support and patient care. Glaxo Pharmaceuticals graciously provided financial support for the research presented.

\section{References}

1. Borum P, Mygind N, Schulz Larsen F (1979) Intranasal ipratropium: a new treatment for perennial rhinitis. Clin Otolaryngol 4:407-411

2. Church MK, Okayama Y, El Lati S (1991) Mediator secretion from human skin mast cells provoked by immunological and non-immunological stimulation. Skin Pharmacol 4:15-24

3. Fokkens WJ, Vroon TM, Gerritsma V, Rijntjes E (1988) A biopsy method to obtain high quality specimens of nasal mucosa. Rhinology 26:293-295 
4. Fokkens WJ, Godthelp T, Holm AF, Blom HM, Mulder PGH Vroom TM, Rijntjes E (1992) Dynamics of mast cells in the nasal mucosa of patients with allergic rhinitis and non allergic controls: biopsy study. Clin Exp Allergy 22:701-710

5. Gerth van Wijk R (1991) Nasal hyperreactivity. Thesis, Rotterdam

6. Irani AA, Bradford TR, Kepley CL, Schechter NM, Schwartz LB (1989) Detection of MCt and MCtc types of human mast cells by immunohistochemistry using new monoclonal antitryptase and anti-chymase antibodies. J Histochem Cytochem 37: 1509-1515

7. Jacobs RL, Freedman PM, Boswell RN (1981) Nonallergic rhinitis with eosinophilia (NARES syndrome). J Allergy Clin Immunol $67: 253-262$

8. Jones AS, Lancer JM (1987) Vasomotor rhinitis (editorial). BMJ 294: 1505-1506

9. Jones AS, Lancer JM, Moir AA, Stevens J (1985) The effect of submucosal diathermy to the inferior turbinates on nasal resistance to airflow in allergic and vasomotor rhinitis. Clin Otolaryngol 10:249-252

10. Klementson H, Svensson C, Anderson M, Venge P, Pipkorn U, Persson CG (1991) Eosinophils, secretory responsiveness and glucocorticoid induced effects on the nasal mucosa during a weak pollen season. Clin Exp Allergy $21: 705-710$

11. Lacroix JS, Pochon N, Lundberg JM (1992) Increased concentration of sensory neuropeptide in the nasal mucosa of patients with non allergic chronic rhinitis. In: Motta G (ed) 2nd European Congress of Oto-Rhino-Laryngology and Cervico-Facial Surgery, 1992, Sorrento, Italy. Monduzzi, Naples

12. Mikaelian AJ (1989) Vasomotor rhinitis. Ear Nose Throat J $68: 207-210$

13. Moqbel R, Barkans J, Brandley BL, Durham SR, Kay AB (1992) Application of monoclonal antibodies against major basic protein (BMK-13) and eosinophil cationic protein (EG1 and EG2) for quantifying eosinophils in bronchial biopsies from atopic asthma. Clin Exp Allergy 22:265-273
14. Mullarkey MF (1988) Eosinophilic nonallergic rhinitis. J Allergy Clin Immunol 82:941-949

15. Mullarkey MF, Hill JS, Webb DR (1980) Allergic and nonallergic rhinitis: their characterization with attention to the meaning of nasal eosinophilia. J Allergy Clin Immunol 65: 122-126

16. Ogale SB, Shah A, Rao SC, Shah KL (1988) Is vidian neurectomy worthwhile? J Laryngol Otol 102:62-63

17. Okuda M, Otsuka H, Kawabori S (1983) Basophil leukocytes and mast cells in the nose. Eur J Respir Dis 64 [Suppl 128]: $7-14$

18. Pipkorn U, Berge T (1983) Long-term treatment with budesonide in vasomotor rhinitis. Acta Otolaryngol (Stockh) $95: 167-171$

19. Selkin SG (1985) Laser turbinectomy as an adjunct to rhinoseptoplasty. Arch Otolaryngol $111: 446-449$

20. Small P, Black M, Frenkiel S (1982) Effects of treatment with beclomethasone diproprionate in subpopulations of perrennial rhinitis patients. J Allergy Clin Immunol 70:178-182

21. Stjarne P, Lundblad L, Lundberg JM, Anggard A (1989) Capsaicin and nicotine-sensitive afferent neurones and nasal secretion in healthy human volunteers and in patients with vasomotor rhinitis. Br J Pharmacol 96:693-701

22. Tai PC, Spry CJF, Peterson C, Venge P, Olsson I (1984) Monoclonal antibodies distinguish between storage and secreted forms of eosinophil cationic peptide. Nature $309: 182-184$

23. Togias AG (1988) The osmolality of nasal secretions increases when inflammatory mediators are released in response to inhalation of cold dry air. Am Rev Respir Dis 137:625-629

24. Wachs M, Proud D, Lichtenstein LM, Kagey-Sobotka A, Norman PS, Naclerio RM (1989) Observations on the pathogenesis of nasal priming. J Allergy Clin Immunol 84:492-501

25. Wihl JA, Kunkel G, Middleton E (1985) Perennial rhinitis. In: Mygind N, Weege B (eds) Allergic and vasomotor rhinitis: clinical aspects. Munksgaard, Copenhagen, p 36

26. Wolf G (1988) New aspects in the pathogenesis and therapy of hyperreflexive rhinopathy. Laryngol Rhinol Otol (Stuttg) 67 : $438-445$ 